\title{
Ebola Virus - A Global Threat
}

\author{
Mejbah Uddin Ahmed ${ }^{1}$, Sushmita Roy ${ }^{2}$ \\ Received: September 6, 2014 Accepted: October 25, 2014 doi: 10.3329/jemc.v5i1.21497
}

\begin{abstract}
Ebola virus is a filamentous, enveloped, non-segmented, single-stranded, negative-sense RNA virus. It belongs to the Filoviridae and was first recognized near the Ebola River valley in Zaire in 1976. Since then most of the outbreaks have occurred to both human and nonhuman primates in sub-Saharan Africa. Ebola virus causes highly fatal hemorrhagic fever in human and nonhuman primates. In addition to hemorrhagic fever, it could be used as a bioterrorism agent. Although its natural reservoir is yet to be proven, current data suggest that fruit bats are the possibility. Infection has also been documented through the handling of infected chimpanzees, gorillas, monkeys, forest antelope and porcupines. Human infection is caused through close contact with the blood, secretion, organ or other body fluids of infected animal. Human-to-human transmission is also possible. Ebola virus infections are characterized by immune suppression and a systemic inflammatory response that causes impairment of the vascular, coagulation, and immune systems, leading to multiorgan failure and shock. The virus constitutes an important public health threat in Africa and also worldwide as no effective treatment or vaccine is available till now.
\end{abstract}

Key words: Ebola virus; Hemorrhagic fever; Fruit bats

J Enam Med Col 2015; 5(1): 44-51

\section{Introduction}

Ebola virus (EV) is the causative agent of the ongoing deadly epidemic in West Africa. It is one of the world's most dreadful pathogens, causing catastrophic clinical disease $^{1}$ and remains one of the most lethal transmissible infections with high fatality rates up to $90 \%$ and substantial morbidity during sporadic outbreaks. ${ }^{2,3}$ High case-fatality rates, as well as known aerosol infectivity, make the virus a potential global health threat and possible biological warfare agent and is classified as category A bioterrorism threats. ${ }^{4-6}$ EBOV together with Marburg virus comprise the family Filoviridae in the order Mononegavirales. ${ }^{7}$ The genus Ebolavirus is comprised of five genetically distinct species: Bundibugyo Ebolavirus (BDBV), Zaire Ebolavirus (ZEBOV), Sudan Ebolavirus (SUDV), Tai Forest Ebolavirus (TAFV) and Reston Ebolavirus (RESTV). ${ }^{8-10}$ Among the five species Zaire, Sudan and Bundibugyo Ebolaviruses are responsible for most of the Ebola hemorrhagic fever (EHF) outbreaks. ${ }^{11}$ Reston
Ebolavirus has caused disease in nonhuman primates but not in humans in the Philippines. ${ }^{12}$ The recent ongoing epidemic is caused by the ZEBOV and has been the most severe outbreak since Ebola virus was first identified in $1976 .{ }^{13}$ No previous outbreak has been as large or persistent as the current epidemic. To date, the number of cases now exceeds the number from all previous outbreaks combined. In addition to mortality, indirect effects include disruption of standard medical care, substantial economic losses, insecurity and social disruption in countries that were already struggling to recover from decades of war. ${ }^{14}$ On August 8, 2014 the World Health Organization (WHO) declared the current epidemic as a Public Health Emergency of International Concern (PHEIC). ${ }^{15}$ Though Ebola infections are generally confined to Central Africa, there is always a risk of spreading to the rest of the world. Furthermore, the virus causes highly fatal disease in human, could be used as a bioterrorism agent

1. Associate Professor, Department of Microbiology, Enam Medical College, Savar, Dhaka

2. Assistant Professor, Department of Microbiology, Enam Medical College, Savar, Dhaka

Correspondence Mejbah Uddin Ahmed, Email:mejbahua@gmail.com 
and at present no effective treatment or vaccine is available. Therefore, people should be aware of the threats from the Ebola virus in order to avoid infection and scientists should try their best to formulate a treatment and vaccine.

\section{History and geographic distribution}

Sporadic outbreaks of Marburg virus and Ebola virus infection have presumably occurred in central Africa for millennia, but the agents were not recognized by the scientific community until the late $20^{\text {th }}$ century. ${ }^{16}$ The cases of filovirus hemorrhagic fever were reported first in 1967 among workers in German and Yugoslavian vaccine plants who were processing tissues from monkeys imported from Uganda. The causative agent was identified as Marburg virus. ${ }^{17,18}$ Similar cases of hemorrhagic fever were described in 1976 from outbreaks in two neighboring locations: first in southern Sudan and subsequently in northern Zaire, now Democratic Republic of the Congo (DRC). An unknown causative agent was isolated from patients in both outbreaks and was named Ebolavirus after a small river in northwestern DRC. ${ }^{19}$ These two epidemics were caused by two distinct species of Ebolavirus, Sudan Ebolavirus and Zaire Ebolavirus. The third African Ebola virus species, Tai Forest Ebolavirus (Côte d'Ivoire Ebolavirus) was discovered in 1994 from an infected ethnologist who had worked in the Tai Forest reserve in Côte d'Ivoire and had done a necropsy on a chimpanzee. Bundibugyo Ebolavirus is the fourth species of Ebola virus found in equatorial Africa. ${ }^{7,20}$ An additional species, the Reston Ebolavirus, was first described in 1989 and isolated from Cynomolgus monkeys (Macaca fascicularis) housed at a quarantine facility in Reston, VA, USA. Subsequently, Reston Ebolavirus has been found in the Philippines on several occasions in pigs. ${ }^{20,21}$ Since the time of first recovery, with the exception of a few accidental laboratory infections, Ebola outbreaks have been mostly concentrated in remote areas of sub-Saharan Africa, but evidence of Ebola infection of swine in the Philippines, the presence of antibodies among orangutans in Indonesia and bats in China indicates that Ebola virus may be more widespread than previously thought. ${ }^{22-24}$ The frequency of recognized outbreaks has been increasing since $1990 .{ }^{25}$ After smaller outbreaks in Zaire and Sudan, some 15 years passed before Ebola virus reappeared in 1994 in Gabon. A large hospital-based epidemic in the Democratic Republic of Congo in 1995 brought the virus to worldwide attention and re-emergence of Sudan Ebolavirus in Uganda in late 2000 resulted in 425 cases and 225 deaths. Epidemics of Zaire Ebolavirus have increased in frequency in recent years. ${ }^{16}$ The virus has caused more than 20 outbreaks since its identification. In most instances, the virus emerged in geographically restricted rural regions. ${ }^{26}$ Outbreak of Ebola virus disease in West Africa is so large and severe; there are many factors behind it, but poverty is considered as the main reason. The hardest-hit countries Guinea, Liberia and Sierra Leone are among the poorest nations and have recently emerged from years of conflict and civil war. Their health systems are destroyed or severely disabled and in some areas war left a generation of children without education. Health care infrastructure is inadequate and health workers and essential supplies including personal protective equipments are scarce. Population movements across the porous borders are constant, so transmission is intense and people continue to reinfect each other. ${ }^{27}$ Traditional practices, such as bathing of corpses before burial, are also an important factor for disease transmission. ${ }^{26}$

\section{Current situation}

The recent ongoing epidemic caused by the Zaire Ebolavirus started in Guinea in December 2013 and then spread to Liberia, Sierra Leone and Nigeria; it is the largest Ebola virus epidemic in history. It has been the most severe outbreak in terms of the number of human cases and fatalities since the discovery of the virus in $1976 .{ }^{13}$ The situation is changing rapidly and other countries might experience imported cases or outbreaks. Instances of civil unrest and violence against aid workers have been reported in West Africa as a result of the outbreak. The public health systems in the affected countries are being severely strained as the outbreak grows. ${ }^{28}$ On 10 December 2014, WHO reported a total of 17,942 suspected cases and 6,388 deaths. ${ }^{29}$

\section{Ebola virus and Bangladesh situation}

Olival et al ${ }^{19}$ conducted a study in Bangladesh during April 2010 to March 2011. They tested 276 bats of several species from Faridpur, Rajbari, Lalmonirhat, and Comilla districts. Among them five bats were positive for antibodies against Ebola Zaire and Reston viruses, but no virus was detected by PCR. There are reasons to speculate that bats might be a reservoir for Ebola or Ebola-like viruses and extend the range of 
filoviruses to mainland Asia. Failure to detect filovirus nucleic acid might reflect the relatively small sample size, low virus prevalence, or use of a PCR that has low sensitivity for filoviruses circulating in Bangladesh. ${ }^{19}$ The national disease monitoring arm Institute of Epidemiology, Disease Control and Research (IEDCR) is keeping a close watch on the current situation. Due to travel restrictions on Ebola patients and the absence of direct air links with the affected West African countries made the deadly virus making its way to Bangladesh "a remote possibility". Director of IEDCR considers Bangladesh a low-risk country and urged everyone not to spread panic. Bangladesh has also issued an alert against Ebola virus for three months, after the WHO declared the epidemic an international health emergency. ${ }^{30}$

\section{Viral structure}

Ebola virus is filamentous, enveloped, non-segmented, single-stranded, negative-sense RNA virus. ${ }^{31,32}$ The EBOV genome is about 19000 nucleotides long that encodes seven structural proteins, nucleoprotein (NP), polymerase cofactor (VP35), matrix protein (VP40), glycoprotein (GP), replication-transcription protein (VP30), minor matrix protein (VP24) and RNA-dependent RNA polymerase (L). ${ }^{33,34}$ The structural proteins VP40 and VP24 represent viral matrix proteins connecting the nucleocapsid with the viral envelope. VP40 plays an essential role in assembly and budding of the virus. ${ }^{35}$ Ebola virus is susceptible to 3\% acetic acid, 1\% glutaraldehyde, alcohol-based products and dilutions of $5.25 \%$ sodium hypochlorite and calcium hypochlorite. The WHO recommendation for cleaning up spills of blood or body fluids is flooding the area with a 1:10 dilution of $5.25 \%$ sodium hypochlorite for 10 minutes. The virus is moderately thermolabile and can be inactivated by heating for 30 to 60 minutes at $60^{\circ} \mathrm{C}$, boiling for 5 minutes or gamma irradiation combined with $1 \%$ glutaraldehyde. It has been reported that the virus is capable to survive for weeks in blood particularly at low temperatures $\left(4^{\circ} \mathrm{C}\right)$. When dried in tissue culture media and stored at $4^{\circ} \mathrm{C}$, Zaire Ebolavirus survived for over 50 days. This information is based on experimental findings and intended to be used to support local risk assessments in a laboratory setting. ${ }^{36}$

\section{Cell tropism and replication}

Ebola virus is known to be pantropic in infection of human and can infect a wide variety of cell types. Though Ebola shows broad tissue tropism, hepatocytes, endothelial cells, dendritic cells, monocytes, and macrophages are thought to be their preferred target cells. ${ }^{31}$ Infection begins with the attachment of the virion to a receptor or lectin on the cell surface. Binding is followed by endocytosis, fusion of the viral envelope with the cellular endosomal membrane and release of the RNA genome and viral proteins into the cytoplasm. A replication complex made up of VP30, nucleoprotein, VP35 and large protein then generates mRNA transcripts. The new genomes associate with nucleoprotein and VP30 to form nucleocapsids which accumulate in inclusion bodies. Meanwhile, newly synthesized viral glycoprotein becomes glycosylated during its transit through the host-cell Golgi apparatus and is cleaved by a furinlike enzyme before transfer to the cell surface, producing extracellular GP1 and transmembrane GP2 segments that remain linked by a disulphide bond. The assembly of new virions takes place on the inner surface of the plasma membrane, when nucleocapsids associate with matrix proteins linked to the cytoplasmic tail of membrane-bound GP. The nascent virions leave the cell through budding. ${ }^{16}$

\section{Natural reservoir}

The first recorded human outbreak of Ebola virus was in 1976, but the wild reservoir of this virus is still unknown. ${ }^{37}$ Since the discovery of filoviruses more than 40 years ago, ostensibly random, sporadic and fatal outbreaks of disease in primates have evoked interest in delineation of host tropisms, potential reservoirs for disease transmission and persistence in nature. ${ }^{8}$ However, researchers have hypothesized that it is an animal origin virus. ${ }^{38}$ Current data suggest that in Africa fruit bats are the possible natural reservoir hosts. As a result, the geographic distribution of Ebola viruses may overlap with the range of the fruit bats. ${ }^{9}$ Infection has also been documented through the handling of infected chimpanzees, gorillas, monkeys, forest antelope and porcupines. ${ }^{13}$

\section{Transmission}

The exact mode of transmission of the virus from the natural reservoir to a human is not known. Evidence suggests that human infection is caused through close contact with the blood, secretion, organ or other body fluids of infected animal. Human-to-human transmission is also possible. ${ }^{9}$ EBOV is shed in a wide variety of body fluids 
(saliva, stool, semen, breast milk, tears, nasal blood and skin swab of infected person) during the acute period of illness. However, the risk of transmission from fomite of a patient and during the convalescent period is low. ${ }^{39}$ It was found that men who have recovered from the disease can still transmit the virus through their semen for up to 7 weeks after recovery from illness. Healthcare workers may get infection through close contact with patients, when infection control precautions are not practiced properly. ${ }^{9}$ Although Ebola virus has been detected in breast milk, it is not known clearly whether Ebola virus can be transmitted through breastfeeding. Infected mothers may be critically ill and unable to breastfeed; but when they are able to breastfeed, decisions about whether or not to breastfeed may depend on the age of the infant, the availability and feasibility of safe nutrition and infant care and overall sanitary conditions. The recommendation of CDC is when safe alternatives to breastfeeding and infant care exist, mothers with probable or confirmed Ebola virus disease should not have close contact with their infants including breastfeeding. ${ }^{40}$

\section{Pathogenesis}

EBOV is an aggressive pathogen that causes highly fatal hemorrhagic fever in human and nonhuman primates. ${ }^{41}$ The virus has the specialized mechanisms to evade the immune system and the course of illness results from a complex pathogenic mechanism. ${ }^{16}$ In a study it is shown that fatal outcome is associated with aberrant innate immune responses and suppression of the adaptive immunity. The innate immune responses are characterized by the hypersecretion of numerous proinflammatory cytokines (IL-1 $\beta$, IL-1RA, IL-6, IL-8, IL-15 and IL-16), chemokines, growth factors (MIP-1 $\alpha$, MIP-1 $\beta$, MCP-1, M-CSF, MIF, IP-10, GRO- $\alpha$ and eotaxin) and by the noteworthy absence of antiviral IFNa2. Suppression of adaptive immunity is characterized by very low levels of circulating cytokines produced by $\mathrm{T}$ lymphocytes and by massive loss of peripheral CD4 and CD8 lymphocytes. ${ }^{37,42}$ Viral replication, in conjunction with immune and vascular dysregulation, is thought to play the vital role in the disease process. Specific organ involvement includes extensive disruption of the parafollicular regions in the spleen and lymph nodes and proliferation of the virus in mononuclear phagocytic cells has been demonstrated. ${ }^{43}$ Studies in nonhuman primate models depicted monocytes, macrophages and dendritic cells are the major sites of initial viral replication. Virus is then distributed by the circulating phagocytic cells to a wide variety of organs and cells. Infected dendritic cell cultures supported exponential viral growth without releasing interferon (IFN- $\alpha$ ). ${ }^{44}$ Two viral proteins (EBOV VP35 and EBOV VP24) are responsible for suppression of interferon responses. It seems that EBOV infection blocks the cellular production of IFN$\alpha / \beta$ and the ability to respond to IFN- $\alpha / \beta$ or IFN- $\gamma$. The VP24 is likely to be an important virulence factor that allows the virus to evade the antiviral effects of IFNs. ${ }^{45,46}$ In most instances, patients fail to produce antibodies against the virus and die with persistent high viremia. For initiation of an adaptive immune response presentation of viral antigens to lymphocytes is required. Phagocytic cells are the major sites of viral replication, which block their maturation and cause their death through necrosis. The system-wide release of proinflammatory cytokines and chemokines by these infected cells causes fever, disseminated intravascular coagulation, vascular instability, hypotension, shock and multi-organ failure. Although lymphocytes remain free of infection, they are destroyed in massive numbers over the course of illness through apoptosis. ${ }^{47}$ Massive apoptosis of natural killer and $\mathrm{T}$ cells further impairs immunity. ${ }^{48}$ Although some studies have shown that survival of the patient is associated with the ability of production of antigen-specific antibodies, a recent report from Sudan suggests that cell-mediated responses could also play an important role in protection. ${ }^{49,50}$ Blood samples obtained during several outbreaks in Gabon also suggested that survival is associated with the earlier appearance of proinflammatory cytokines in the blood. ${ }^{51}$

\section{Clinical features}

Clinical findings are variable in Ebola infection. After an incubation period of around 2-21 days, ${ }^{4}$ disease starts nonspecifically with the abrupt onset of fever, chills, headache, malaise, anorexia, sore throat, myalgia and joint pains. ${ }^{20,46}$ The initial features of the disease may mimic other tropical diseases and it is difficult to distinguish these features from other febrile illnesses. Conjunctival infection is seen in up to half of the patients. ${ }^{46}$ Respiratory symptoms include chest pain, shortness of breath, dry cough and nasal discharge. ${ }^{20}$ Gastrointestinal manifestations including nausea, vomiting, abdominal pain and diarrhea develop within the first few days of illness. In severe cases, vascular 
instability develops, usually 4-5 days after the onset of symptoms and may be evidenced by facial flushing, edema, proteinuria, bleeding, hypotension and shock. ${ }^{46}$ Maculopapular rash associated with varying severity of erythema appears which desquamates by day 5-7 of the illness; this symptom is a valuable differential diagnostic feature and is usually followed by desquamation in survivors. ${ }^{20}$ Hemorrhage is most often gastrointestinal but vaginal bleeding, petechie, purpura, epistaxis and bleeding from the gums may be seen. Central nervous system manifestations including disorientation, gait anomalies, convulsions and hiccups may also be noted in end-stage disease. ${ }^{46}$

\section{Laboratory diagnosis}

In the absence of effective intervention strategies, diagnosis becomes a key element in response to Ebola virus infection. Diagnosis of EHF must be sensitive, specific and reliable because misdiagnosis may bring huge turmoil to society. Therefore, the diagnosis of EHF must not rely on any single method. During outbreak, patients with EHF must be isolated and a false-positive result will put an individual at unnecessary risk of cross infection by placing the person in an isolation ward. A false-negative result will allow infected persons to be released into the community and may cause person-to-person transmission of the virus in the community. ${ }^{52}$ Laboratory diagnosis of Ebola virus is achieved in two ways: measurement of host-specific immune responses to infection and detection of viral particles or particle components in infected individuals. ${ }^{20}$ Therefore, the diagnosis rests largely on molecular techniques utilizing multiple reverse-transcriptase-polymerase-chainreaction assays that can be used at remote outbreak sites. Antigen detection may be performed in parallel or serve as a confirmatory test for immediate diagnosis whereas assays for detection of antibodies (IgM and $\mathrm{IgG})$ using unique virus antigens are secondary tests that are primarily important in surveillance. ${ }^{53,54}$ Definitive diagnosis is usually made by PCR and virus isolation on Vero cells. As a class-4 pathogen, Ebola virus culture requires a maximum containment facility. Additional immunological tests include ELISAs for the detection of Ebola IgG- and IgM-specific antibodies and virus antigens; more specialized molecular testing is also available but is not readily available in the usual clinical setting. ${ }^{11}$ Now-a-days, RT-PCR and antigen detection ELISA are the primary assays to diagnose an acute infection. Viral antigen and nucleic acid can be detected in blood from day 3 up to 7-16 days after onset of symptoms. For antibody detection the most generally used assays are direct IgG and IgM ELISAs and IgM capture ELISA. IgM antibodies can appear as early as 2 days postonset of symptoms and disappear between 30 and 168 days after infection. IgG-specific antibodies develop between day 6 and 18 after onset and persist for many years. An IgM or rising IgG titer constitutes a strong presumptive diagnosis. Decreasing $\operatorname{IgM}$ or rising IgG titers (four-fold), or both, in successive paired serum samples are highly suggestive of a recent infection. ${ }^{20}$ Histopathological techniques and antigen detection by immunohistochemical analyses are sensitive methods, particularly for postmortem diagnosis. Diagnosis by detection of virus antigens is suitable for patients in the early stage and detection of specific $\operatorname{IgM}$ and $\operatorname{IgG}$ antibodies is suitable for patients in a relatively late stage of illness. ${ }^{48}$

\section{Treatment}

EBOV infections are a public health concern because of the high mortality rate and lack of prophylactic and therapeutic interventions as no specific antiviral treatment is available at present. ${ }^{55}$ Severely ill patients require intensive supportive care which includes oxygen, blood pressure medication, blood transfusions, rehydration with intravenous fluids containing electrolytes and treatment for other infections. ${ }^{9}$ A study done by Qiu et al in 2012 shows that a combination of three neutralizing monoclonal antibodies directed against the envelope glycoprotein resulted in complete survival of four of four cynomolgus macaques with no apparent side effects when three doses were administered 3 days apart beginning at 24 hours after a lethal challenge with EBOV. The same treatment initiated 48 hours after resulted in two of four cynomolgus macaques fully recovering. ${ }^{56}$

\section{Prevention}

Although safe and effective vaccines or other medicinal agents to block Ebola infection are currently unavailable, a significant effort has been put forth to identify several promising candidates for the treatment and prevention. 2,57 Some vaccines under trial have been shown to protect NHPs: a replication-incompetent adenovirus expressing the EBOV glycoprotein (29-31), a replication-competent vesicular stomatitis virus (VSV) expressing GP $(7,15)$, a recombinant 
paramyxovirus expressing GP (4), and virus-like particles $(38,41) .{ }^{5}$ In the absence of effective treatment and vaccine, raising awareness regarding the risk factors and personal protective measures is the only way to reduce human infection and death. ${ }^{9}$ There are three key preventive interventions which have gained attention with encouraging outcome. The first is meticulous infection control in health care settings. Second is educating and supporting the community to avoid contact with body fluids of people who died from EVD, at least temporarily until the outbreak is controlled. And the third is avoiding handling of bush meat and contact with bats. ${ }^{14}$

\section{Conclusion}

The main goal currently being addressed with Ebola virus is finding ways of treatment and effective vaccines that can be applied to humans. Although Ebola virus infection is not a problem right now for most populations outside Africa, it has the potential to be alarming from the point of view in global health in the future.

\section{References}

1. Goodman JL. Studying "Secret Serums" - toward safe, effective Ebola treatments. N Engl J Med 2014; 371(12): 1086-1089. doi: 10.1056/NEJMp1409817.

2. Oestereich L, Ludtke A, Wurr S, Rieger S, Munoz-Fontela C, Günther S. Successful treatment of advanced Ebola virus infection with T-705 (favipiravir) in a small animal model. Antiviral Research 2014: 105: 17-21.

3. Pettitt J, Zeitlin L, Kim DH, Working C, Johnson JC, Bohorov $\mathrm{O}$ et al. Therapeutic intervention of Ebola virus infection in Rhesus macaques with the mb-003 monoclonal antibody cocktail. Sci. Transl. Med. 2013; 5: 199 ra113.

4. Ustun C, Ozgurler O. Ebola: a significant threat as an infectious disease and as a potential bioterrorism agent. Turk J Med Sci 2005; 35: 1-4.

5. Halfmann P, Ebihara H, Marzi A, Hatta Y, Watanabe S, Suresh $M$ et al. Replication-deficient Ebolavirus as a vaccine candidate. Journal of Virology 2009; 83(8): 3810-3815.

6. Warfield KL, Bosio CM, Welcher BC, Deal EM, Mohamadzadeh M, Schmaljohn A et al. Ebola virus-like particles protect from lethal Ebola virus infection. PNAS 2003; 100(26): 15889-15894.

7. Towner JS, Sealy TK, Khristova ML, Albariño CG, Conlan S, Reeder SA et al. Newly discovered Ebola virus associated with hemorrhagic fever outbreak in Uganda. PLoS Pathog 2008; 4(11): e1000212. doi:10.1371/journal.ppat.1000212.

8. Barrette RW, Metwally SA, Rowland JM, Xu L, Zaki SR, Nichol ST e al. Discovery of swine as a host for the Reston Ebolavirus. Science 2009; 325(5937): 204-206.

9. Ebola virus disease. World Health Organization. Fact sheet. Available at: http://www.who.int/mediacentre/factsheets/ fs103/en/. Accessed September 2014.

10. Negredo A, Palacios G, Vázquez-Morón S, González F, Dopazo H, Molero F et al. Discovery of an Ebolavirus-like Filovirus in Europe. PLoS Pathog 2011; 7(10): e1002304. doi: 10.1371/journal.ppat.1002304.

11. Muyembe-Tamfum J, Mulangu S, Masumu J, Kayembe JM, Kemp A, Paweska JT. Ebola virus outbreaks in Africa: past and present. Onderstepoort J Vet Res 2012; 179(2): 451.

12. Sayama Y, Demetria C, Saito M, Azul RR, Taniguchi S, Fukushi S et al. A seroepidemiologic study of Reston ebola virus in swine in the Philippines. BMC Veterinary Research 2012; 8: 82.

13. 2014 West Africa Ebola virus outbreak. Wikipedia, the free encyclopedia. Available at: http://en.wikipedia.org/wiki/. Accessed September 2014.

14. Frieden TR, Damon I, Bell BP, Kenyon T, Stuart Nichol. Ebola 2014 - new challenges, new global response and responsibility. N Engl J Med 2014; 371(13): 1177-1180. doi: 10.1056/NEJMp1409903.

15. Briand S, Bertherat E, Cox P, Formenty P, Kieny M, Myhre JK et al. The international Ebola emergency. N Engl J Med 2014; 371(13): 1180-1183. doi: 10.1056/NEJMp1409858.

16. Mahanty S, Bray M. Pathogenesis of filoviral haemorrhagic fevers. The Lancet Infectious Diseases 2004; 4 (8): $487-498$.

17. Amman BR, Carroll SA, Reed ZD, Sealy TK, Balinandi S et al. Seasonal pulses of Marburg virus circulation in juvenile Rousettus aegyptiacus bats coincide with periods of increased risk of human infection. PLoS Pathog 2012; 8(10): e1002877. doi:10.1371/journal.ppat.1002877.

18. Brauburger K, Hume AJ, Mühlberger E, Olejnik J. Fortyfive years of Marburg virus research. Viruses 2012; 4: 1878-1927.

19. Olival KJ , Islam A, Yu M, Anthony SJ, Epstein JH, Khan SA et al. Ebola virus antibodies in fruit bats. Available at: http://wwwnc.cdc.gov/eid/article/19/2/pdfs/12-0524.pdf. Accessed August 2014.

20. Feldmann H, Geisbert TW. Ebola haemorrhagic fever. The Lancet 2011: 377(9768): 849 -862.

21. Miranda MEG, Miranda NLJ. Reston ebolavirus in humans 
and animals in the Philippines: a review. Journal of Infectious Diseases 2011; 204(3): 757-760.

22. Falzarano D, Geisbert TW, Feldmann H. Progress in filovirus vaccine development: evaluating the potential for clinical use. Expert Rev Vaccines 2011; 10(1): 63-77.

23. Qiu X, Wong G, Fernando L, Ennis J, Turner JD, Alimonti JB et al. Monoclonal antibodies combined with AdenovirusVectored interferon significantly extend the treatment window in Ebola virus-infected guineapigs. J Virol 2013; 87(13): 7754-7757.

24. Nidom CA, Nakayama E, Nidom RV, Alamudi MY, Daulay S, Dharmayanti INLP et al. Serological evidence of Ebola virus infection in Indonesian Orangutans. PLoS One 2012; 7(7): e40740.

25. Bray M. Epidemiology, pathogenesis and clinical manifestations of Ebola and Marburg virus disease. Available at: http://pmtwww.uptodate.com/contents/ epidemiology-pathogenesis-and-clinical-manifestations-ofebola-and-marburg-virus-disease? source $=$ search_result\& search $=$ Marburg+virus + infection\&selected Title $=1 \sim 3$. Accessed September 2014.

26. Fauci AS. Ebola-underscoring the global disparities in health care resources. N Engl J Med 2014; 371(12): 1084-1086. doi: 10.1056/NEJMp140949.

27. Chan M. Ebola virus disease in West Africa - no early end to the outbreak. N Engl J Med 2014; 371(13): 1183-1185. doi: 10.1056/NEJMp1409859.

28. Ebola outbreak: advice for humanitarian aid organizations. Centers for Disease Control and Prevention. Available at: http://wwwnc.cdc.gov/travel/page/advice-humanitarian-aidorganizations-ebola. Accessed September 2014.

29. Global alert and response (GAR). Ebola response roadmapsituation report. Available at: www.whoint/csr/disease/ ebola/situation-reports/en/. Accessed December 2014. .

30. Bangladesh issues Ebola alert. Available at: http:// www.business-standard.com/article/pti-stories/bangladeshissues-ebola-alert-114081100256_1.html. Accessed August 2014.

31. Takada A. Filovirus tropism: cellular molecules for viral entry. Frontiers in Microbiology 2012; 3: 34.

32. Sullivan N, Yang Z, Nabel GJ. Ebola virus pathogenesis: implications for vaccines and therapies. Journal of Virology 2003; 77(18): 9733-9737.

33. Becquart P, Wauquier N, Mahlakoiv T, Nkoghe D, Padilla C, Souris $\mathrm{M}$ et al. High prevalence of both humoral and cellular immunity to Zaire ebolavirus among rural populations in Gabon. PLoS ONE 2010; 5(2): e9126. doi:10.1371/ journal.pone.0009126.
34. Yasuda J. Ebolavirus replication and tetherin/BST-2. Frontiers in Microbiology 2012; 3: 111. doi: 10.3389/ fmicb.2012.00111.

35. Lucht A, Grunow R, Otterbein C, Moller P, Feldmann H, Becker S. Production of monoclonal antibodies and development of an antigen capture ELISA directed against the envelope glycoprotein GP of Ebola virus. Med Microbiol Immunol 2004; 193: 181-187.

36. Ebolavirus. Pathogen safety data sheet - infectious substances. Available at: http://www.phac-aspc.gc.ca/labbio/res/psds-ftss/ebola-eng.php\#footnote48. Accessed September 2014.

37. Leroy EM, Becquart P, Wauquier N, Sylvain Baize. Evidence for Ebola virus superantigen activity. Journal of Virology 2011; 85(8): 4041-4042.

38. MacNeil A, Rollin PE. Ebola and Marburg hemorrhagic fevers: neglected tropical diseases? PLoS Negl Trop Dis 2012; 6(6): e1546. doi:10.1371/journal.pntd.0001546.

39. Bausch DG, Towner JS, Dowell SF, Kaducu F, Lukwiya M, Sanchez A et al. Assessment of the risk of Ebola virus transmission from bodily fluids and fomites. Journal of Infectious Diseases 2007; 196(2): 142-147.

40. Ebola virus disease. Centers for Disease Control and Prevention. Recommendations for breastfeeding/infant feeding in the context of Ebola. Available at: http://www.cdc. gov/vhf/ebola/hcp/recommendations-breastfeeding-infantfeeding-ebola.html. Accessed September 2014.

41. Casillas AM, Nyamathi AM, Sosa A, Wilder CL, Sands H. A current review of Ebola virus: pathogenesis, clinical presentation, and diagnostic assessment. Biological Research For Nursing 2003; 4(4): 268-275.

42. Wauquier N, Becquart P, Padilla C, Baize S, Leroy EM. Human fatal Zaire Ebola virus infection is associated with an aberrant innate immunity and with massive lymphocyte apoptosis. PLoS Negl Trop Dis 2010; 4(10): e837.

43. Bente D, Gren J, Strong JE, Feldmann H. Disease modeling for Ebola and Marburg viruses. Dis Model Mech 2009; 2(1-2): 12-17.

44. Bosio CM, Aman MJ, Grogan C, Hogan R, Ruthel G, Negley $\mathrm{D}$ et al. Ebola and Marburg viruses replicate in monocytederived dendritic cells without inducing the production of cytokines and full maturation. J Infect Dis 2003; 188(11): 1630-1638.

45. Basler CF, Mikulasova A, Martinez-Sobrido L, Paragas J, Mühlberger E, Bray M et al. The Ebola virus VP35 protein inhibits activation of interferon regulatory factor 3. J Virol 2003; 77(14): 7945-7956.

46. Reid SP, Leung LW, Hartman AL, Martinez O, Shaw ML, Carbonnelle $\mathrm{C}$ et al. Ebola virus VP24 binds karyopherin 
alpha1 and blocks STAT1 nuclear accumulation. J Virol 2006; 80(11): 156-167.

47. Bausch DG, Sprecher AG, Jeffs B, Boumandouki P. Treatment of Marburg and Ebola hemorrhagic fevers: a strategy for testing new drugs and vaccines under outbreak conditions. Antiviral Research 2008; 78: 150-161.

48. Bray M, Geisbert TW. Ebola virus: the role of macrophages and dendritic cells in the pathogenesis of Ebola hemorrhagic fever. The International Journal of Biochemistry \& Cell Biology 2005; 37(8): 1560-1566.

49. Ksiazek TG, Rollin PE, Williams AJ, Bressler DS, Martin ML, Swanepoel R et al. Clinical virology of Ebola hemorrhagic fever (EHF): virus, virus antigen, and $\operatorname{IgG}$ and IgM antibody findings among EHF patients in Kikwit, Democratic Republic of the Congo, 1995. J Infect Dis 1999; 179(Suppl 1): S177-S187.

50. Towner JS, Rollin PE, Bausch DG, Sanchez A, Crary SM, Vincent $\mathrm{M}$ et al. Rapid diagnosis of Ebola hemorrhagic fever by reverse transcription-PCR in an outbreak setting and assessment of patient viral load as a predictor of outcome. J Virol 2004; 78(8): 4330-4341.

51. Baize S, Leroy EM, Georges-Courbot MC, Capron M, Lansoud-Soukate J, Debré $\mathrm{P}$ et al. Defective humoral responses and extensive intravascular apoptosis are associated with fatal outcome in Ebola virus-infected patients. Nat Med 1999; 5(4): 423-426.

52. Saijo M, Niikura M, Ikegami T, Kurane I, Kurata T, Morikawa S. Laboratory diagnostic systems for Ebola and Marburg hemorrhagic fevers developed with recombinant proteins. Clin Vaccine Immunol 2006; 13 (4): 444-451.

53. Zaki SR, Shieh WJ, Greer PW, Goldsmith CS, Ferebee T, Katshitshi $\mathrm{J}$ et al. A novel immunohistochemical assay for the detection of Ebola virus in skin: implications for diagnosis, spread, and surveillance of Ebola hemorrhagic fever. The Journal of Infectious Diseases 1999; 179(1): $36-47$.

54. Feldmann H. Ebola - a growing threat? N Engl J Med 2014; 371(15): 1375-1378. doi: 10.1056/NEJMp1405314.

55. Nakayama E, Takada A. Ebola and Marburg viruses. Journal of Disaster Research 2011: 6(4): 381-382.

56. Qiu X, Audet J, Wong G, Pillet S, Bello A, Cabral T et al. Successful treatment of Ebola virus-infected cynomolgus macaques with monoclonal antibodies. Sci Transl Med 2012: 4(138): 138ra81.

57. Choi JH, Croyle MA. Emerging targets and novel approaches to ebola virus prophylaxis and treatment. Bio Drugs 2013; 27(6): 565-583. 